\title{
Współczesne procesy internacjonalizacji produkcji i delokalizacji przemysłu samochodowego Francji
}

\section{WPROWADZENIE}

Globalizacja jest współcześnie typowym i powszechnym zjawiskiem występującym we wszystkich sektorach gospodarki świata. Również przedsiębiorstwa branży motoryzacyjnej budują swoją przewagę konkurencyjną, wykorzystując procesy globalizacji. Efektem tego są przede wszystkim zmiany struktury własnościowej koncernów (koncentracja kapitałowa) oraz delokalizacja produkcji w skali całego świata. W ostatnich latach operacje delokalizacji produkcji stały się integralnym elementem długoterminowej strategii działalności wielu koncernów motoryzacyjnych. Delokalizacja produkcji ma zapewnić koncernom uzyskanie lepszej pozycji konkurencyjnej w walce o klienta, a przez to zwiększyć generowane zyski.

Zjawisko delokalizacji jest złożone i uwarunkowane splotem różnych czynników tkwiących zarówno w przedsiębiorstwie, jak i w jego makrootoczeniu. Podstawowym motywem relokalizacji produkcji jest chęć obniżenia kosztów produkcji i zwiększenia elastyczności działania przedsiębiorstwa. Innymi czynnikami wpływającymi na delokalizację są: jakość i kwalifikacje zasobów pracy, dostępność rynków zaopatrzenia i zbytu, zasady opodatkowania przedsiębiorstw, infrastruktura oraz ramy instytucjonalne. Upowszechnienie reguł gospodarki rynkowej na całym niemal świecie daje inwestorom swobodę wyboru lokalizacji. Na pierwsze miejsce w lokalizacji inwestycji wysunęły się współcześnie regiony Azji oraz Ameryki Południowej, dystansując region Europy Środkowo-Wschodniej. Kraje te dysponują olbrzymią rezerwą taniej siły roboczej, co w naturalny sposób predysponuje je do skupienia się na produkcji wyrobów pracochłonnych. Ponadto obecność zagranicznych inwestycji wpływa na wzrost gospodarczy oparty na eksporcie oraz umożliwia korzystanie z doświadczenia, technologii i know-how światowych koncernów (Moszyński 2007, s. 39). Wszystkie wymienione powyżej procesy zachodzą we współczesnym przemyśle samochodowym Francji.

Tematem artykułu są współczesne procesy internacjonalizacji produkcji i delokalizacji przemysłu samochodowego, ze szczególnym uwzględnieniem Francji. W oparciu o dane statystyczne odnoszące się do wielkości produkcji oraz jej struktury przedstawiono zmiany w koncentracji produkcji samochodów na świecie, ze szczególnym uwzględnieniem francuskich koncernów samochodowych. Dane pochodzą z opracowań Comité des Constructeurs Français d'Automobiles: Analysis and statistics the French automotive in- 
dustry; Tableau de bord automobile oraz z danych European Automobile Manufacturers' Association, które obejmują lata 1997-2008.

W treści artykułu dokonano próby potwierdzenia istnienia wyraźnych tendencji zmiany lokalizacji produkcji przemysłu samochodowego (w tym głównie zmniejszenia znaczenia kontynentu europejskiego w produkcji samochodów) oraz wskazania regionów świata, do których przemysł ten zostaje przeniesiony. Zagadnieniami delokalizacji produkcji w ujęciu procesów globalizacji zajmowali się całościowo m.in.: A. Deardorff (2004, 2005), P.A. Samuelson (2004), M.J. Radło (2006) i W. Gierańczyk (2008). Również procesy zachodzące w koncernach samochodowych były przedmiotem licznych opracowań, por. m.in. P. Pavlínek (2009), B. Domański, R. Guzik (2005, 2009), K. Gwosdz (2005), A. Merkisz-Guranowska, J. Merkisz (2007), W. Kilar, M. Cieluch (2008), M. Wójtowicz (2008, 2009).

\section{STRUKTURA GEOGRAFICZNA PRODUKCJI SAMOCHODÓW NA ŚWIECIE}

Znaczenie przemysłu motoryzacyjnego dla rozwoju gospodarczego w ujęciu tzw. efektu mnożnikowego (jedna osoba zatrudniona w przemyśle samochodowym tworzy około czterech miejsc pracy w innych gałęziach gospodarki) było opisywane przez wielu badaczy tematu (Wiedermann 2007, 2008). Szczególne znaczenie motoryzacji wśród innych sektorów przemysłowych ujawniło się w sytuacji kryzysu finansowego, który odczuli nie tylko producenci samochodów, ale również przedstawiciele całego łańcucha dostawczego, zdominowanego głównie przez małe i średnie przedsiębiorstwa (Polityka regionalna mająca na celu walkę z kryzysem ekonomicznym. Zgromadzenie Regionów Europy (AER) 2009).

Analizując wielkość światowej produkcji przemysłu motoryzacyjnego, można zauważyć dwie tendencje. Po pierwsze, od lat osiemdziesiątych XX w. nastapił spadek udziału produkcji w Europie (spadek z 36,9\% do 30,9\%) oraz w Ameryce Południowej (z 25,1\% do 18,4\%). Natomiast w regionie azjatyckim udział produkcji samochodów wzrósł z 31,0\% do 44,3\%. Również w Ameryce Południowej w badanym okresie nastąpił wzrost produkcji przemysłu motoryzacyjnego z 3,5\% w 1980 r. do 5,6\% w 2008 r. produkcji światowej samochodów. Po drugie, przełomowym okresem w zmianie lokalizacji przemysłu samochodowego był rok 2000, w którym nastąpiło wyraźne obniżenie produkcji w Europie i Ameryce Południowej na korzyść regionów Azji i Pacyfiku.

W odniesieniu do wybranych państw analizowanych regionów można przyjąć, że w dalszym ciagu w Europie, Azji oraz Ameryce Północnej produkcja samochodów jest domeną krajów rozwiniętych, tj. Japonii, USA czy krajów Europy Zachodniej. Jednakże we wszystkich przypadkach w państwach tych następuje spadek produkcji na rzecz krajów rozwijających się, tj. Chin, Indii, Meksyku i Europy Wschodniej. Odmienne tendencje występują w Ameryce Południowej, gdzie produkcja samochodów rośnie w większości krajów. Dlatego region ten odnotował największy wzrost produkcji samochodów w badanym okresie (ryc. 2). 


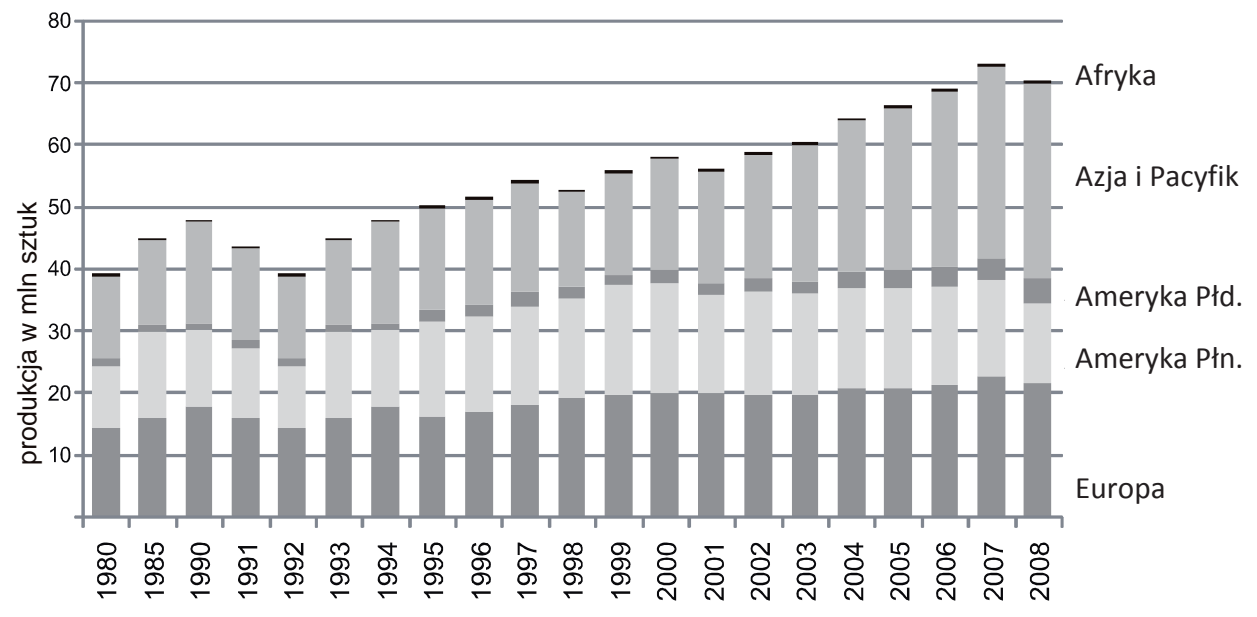

Ryc. 1. Wielkość światowej produkcji przemysłu samochodowego w latach 1980-2008

Źródło: opracowanie własne na podstawie danych European Automobile Manufacturers’ Association
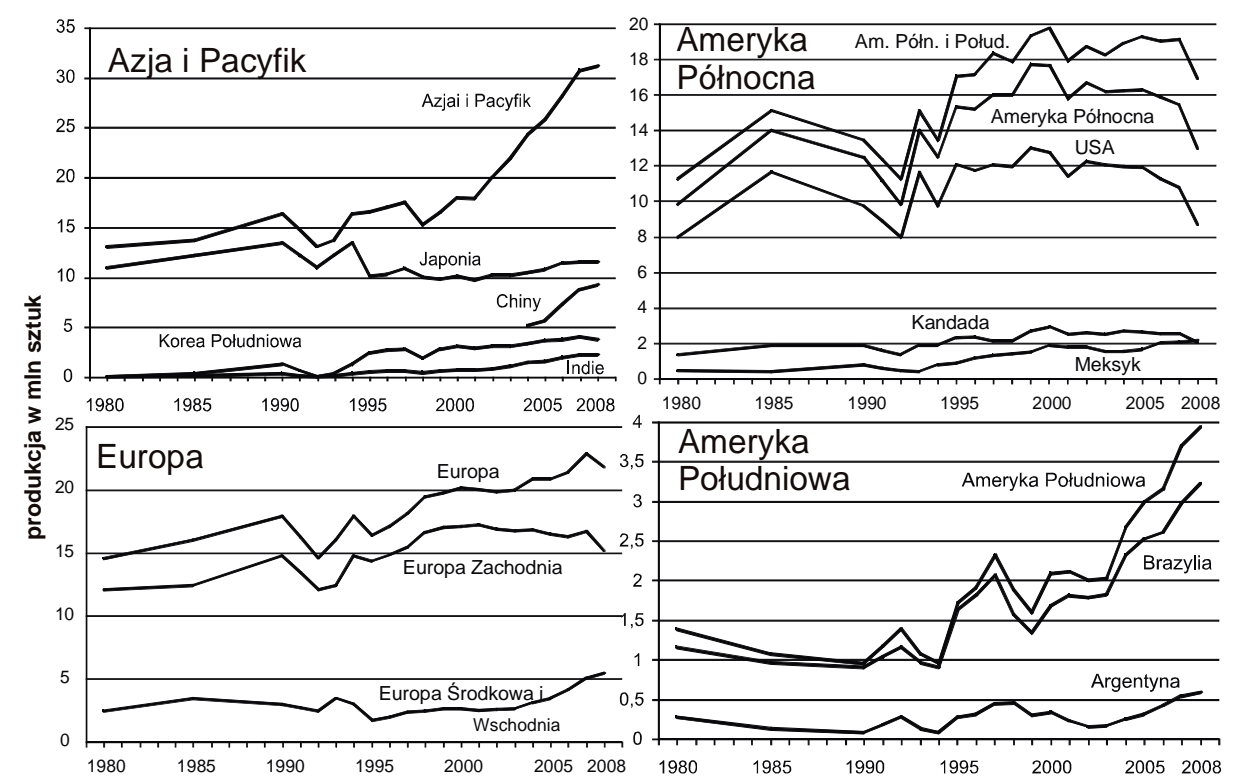

Ryc. 2. Zmiany udziału w produkcji samochodów wg regionów świata i państw w latach 1980-2008

Źródło: opracowanie własne na podstawie danych European Automobile Manufacturers’ Association 

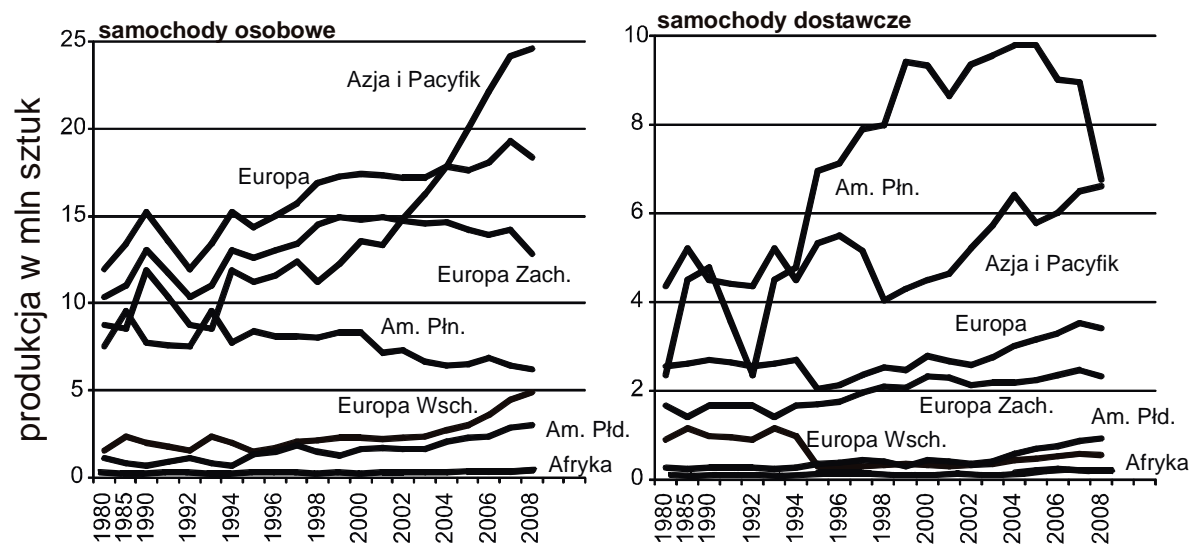

Ryc. 3. Wielkość produkcji przemysłu samochodowego wg regionów i rodzaju pojazdu w latach 1980-2008

Źródło: opracowanie własne na podstawie danych European Automobile Manufacturers’ Association

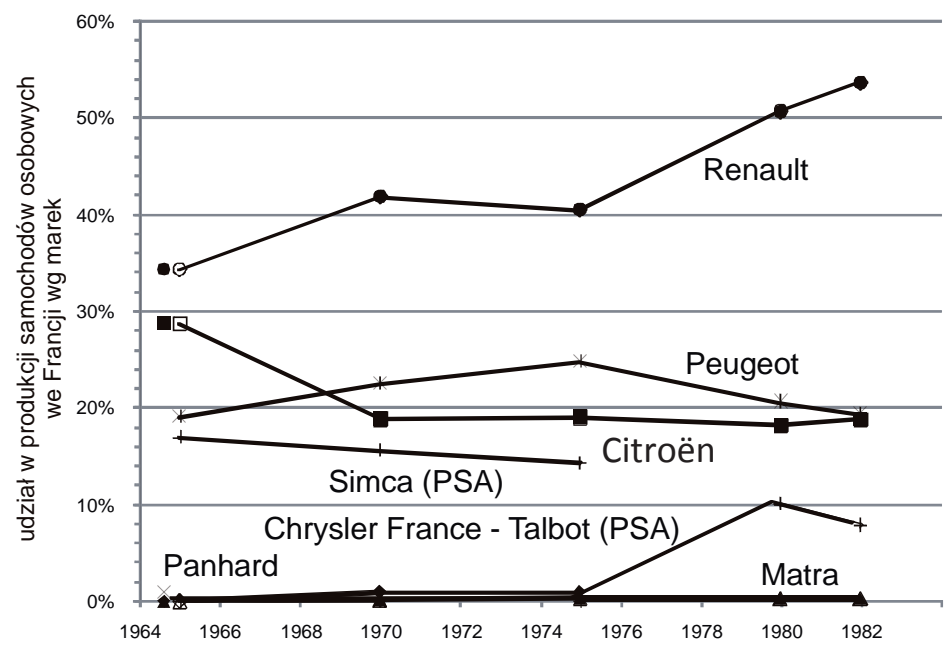

Ryc. 4. Produkcja samochodów osobowych we Francji wg marek w latach 1964-1982

Źródło: opracowanie własne na podstawie danych European Automobile Manufacturers’ Association

Można zaobserwować także wyraźne zróżnicowanie rodzaju produkowanych pojazdów samochodowych. Produkcja samochodów osobowych stanowi ponad $70 \%$ ogółu produkcji przemysłu motoryzacyjnego. W przypadku samochodów dostawczych spadek produkcji w Europie Zachodniej i USA nie jest już tak wyraźny (gwałtowny spadek produkcji w USA wydaje się być jedynie wynikiem kryzysu finansowego - ryc. 3). 


\section{PrZEMYSŁ SAMOCHODOWy FranCJI}

Początki przemysłu samochodowego we Francji sięgają XIX w., kiedy to firmy PanhardLevassor i De Dion-Bouton wypuściły na rynek pierwsze w świecie popularne pojazdy oraz pierwsze luksusowe pojazdy produkowane seryjnie. Jednakże mimo pojawienia się innych znanych marek francuskich samochodów (Bugatti), jedynie nazwiska dwóch ludzi Louisa Renaulta i Andre Citroëna kojarzą się ściśle z rozwojem francuskiego przemysłu motoryzacyjnego. To właśnie te dwa koncerny samochodowe (Renault i PSA Peugeot Citroën) odpowiadają za prawie całą produkcję przemysłu samochodowego Francji (ryc. 4 i 5). W okresie powojennym Francja zajmowała drugie miejsce w produkcji samochodów w Europie, zaraz po Niemczech. Jednakże od lat dziewięćdziesiątych XX w. nastąpił wyraźny spadek produkcji (ryc. 6).

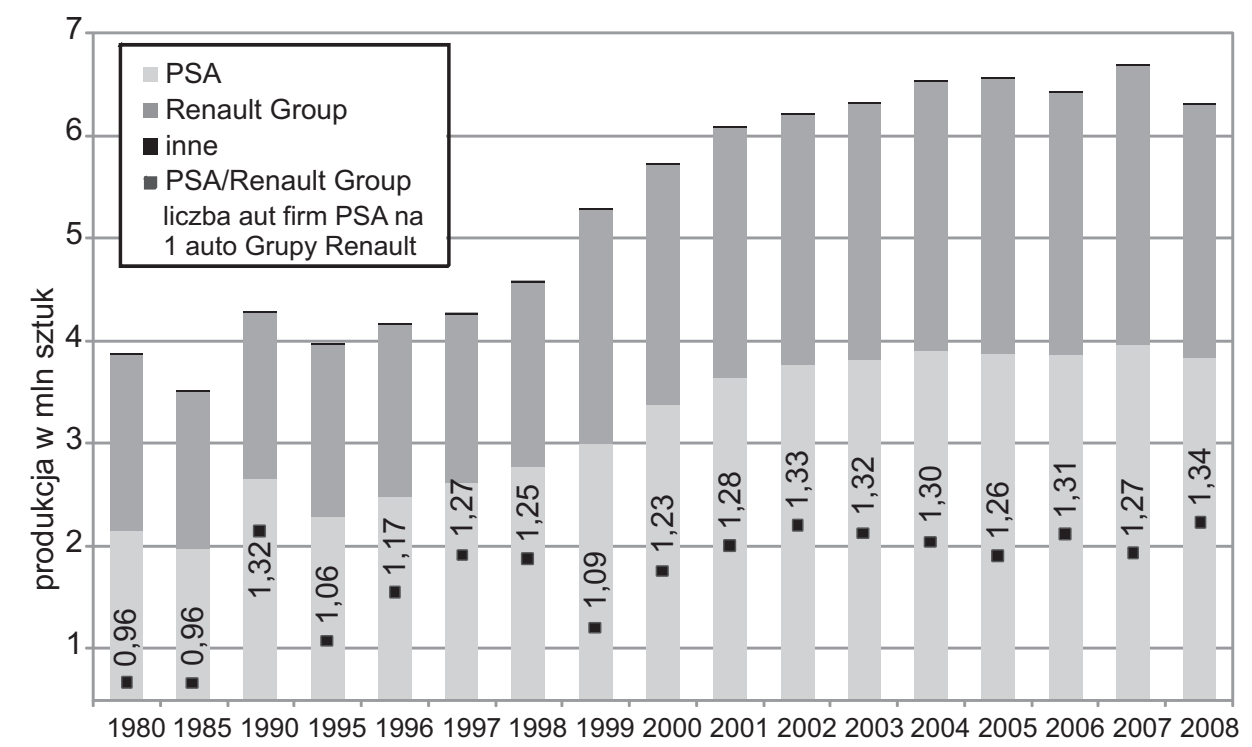

Ryc. 5. Produkcja francuskich koncernów samochodowych w latach 1980-2008

Źródło: opracowanie własne na podstawie danych Comité des Constructeurs Français d'Automobiles

Spadek wielkości produkcji samochodów we Francji (ryc. 6) wraz ze wzrostem produkcji francuskich koncernów samochodowych (ryc. 5) świadczy o procesie przenoszenia produkcji poza terytorium Francji. Dotyczy to głównie produkcji samochodów osobowych i dostawczych do 5 ton, która w ponad 65\% skupiona jest poza granicami Francji (ryc. 7, 8). Dzieląc produkcję według marek, można stwierdzić, że najwięcej samochodów poza Francją wytwarza koncern PSA (prawie 2 mln sztuk), w tym głównie Citroën - 1,2 mln, podczas gdy koncern Renault 1,7 mln. Analizując udział produkcji zagranicznej w ogóle produkcji, widzimy, że w przypadku Renault jest to $70 \%$, podczas gdy w przypadku PSA $60 \%$ (ryc. 9). 


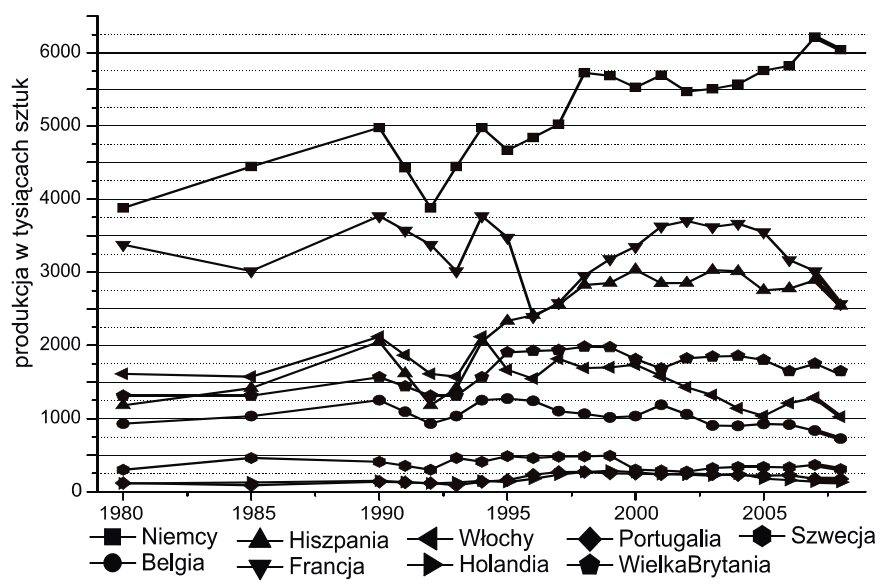

Ryc. 6. Produkcja samochodów w wybranych krajach Europy Zach. w latach 1980-2008 Źródło: opracowanie własne na podstawie danych Comité des Constructeurs Français d'Automobiles
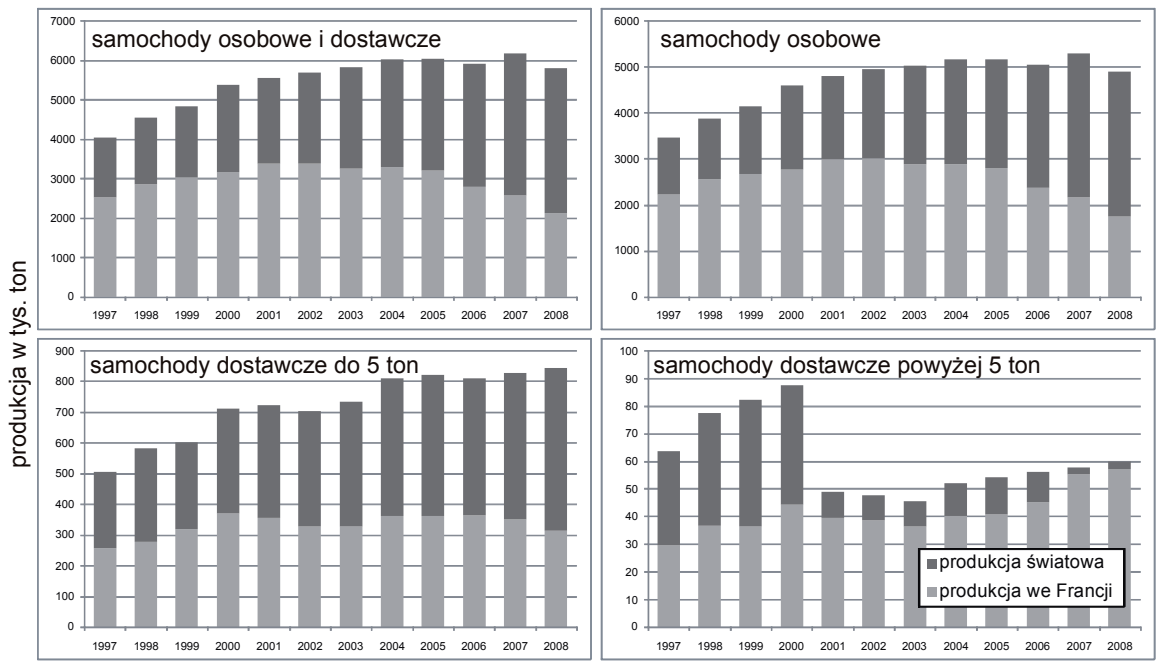

Ryc. 7. Produkcja francuskich koncernów samochodowych w latach 1980-2008

Źródło: opracowanie własne na podstawie danych Comité des Constructeurs Français d'Automobiles

Koncerny francuskie przenosiły swoją produkcję głównie do krajów europejskich (71\% ogółu produkcji) oraz do Azji i Ameryki Południowej. Spośród państw europejskich na pierwszym miejscu plasuje się Hiszpania z ponad 35\% udziałem produkcji zagranicznej koncernów francuskich, następnie jest Turcja $(8,19 \%)$ oraz kraje Europy Wschodniej (Słowacja, Czechy, Słowenia, Rumunia - 24\%). Z państw pozaeuropejskich największą produkcją charakteryzuje się Brazylia (5,02\%), Chiny (4,86\%), Korea Południowa (4,25\%) oraz Argentyna $(3,69 \%)$. 


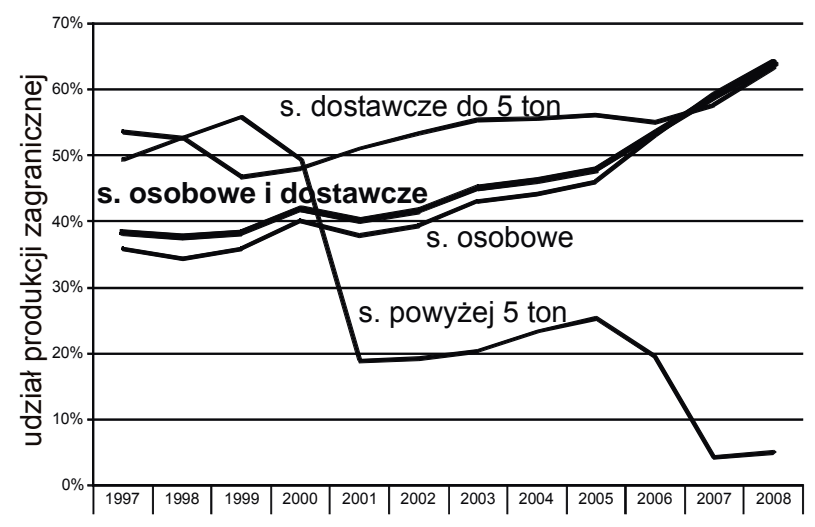

Ryc. 8. Produkcja francuskich samochodów poza Francją w latach 1997-2008

Źródło: opracowanie własne na podstawie danych Comité des Constructeurs Français d’Automobiles
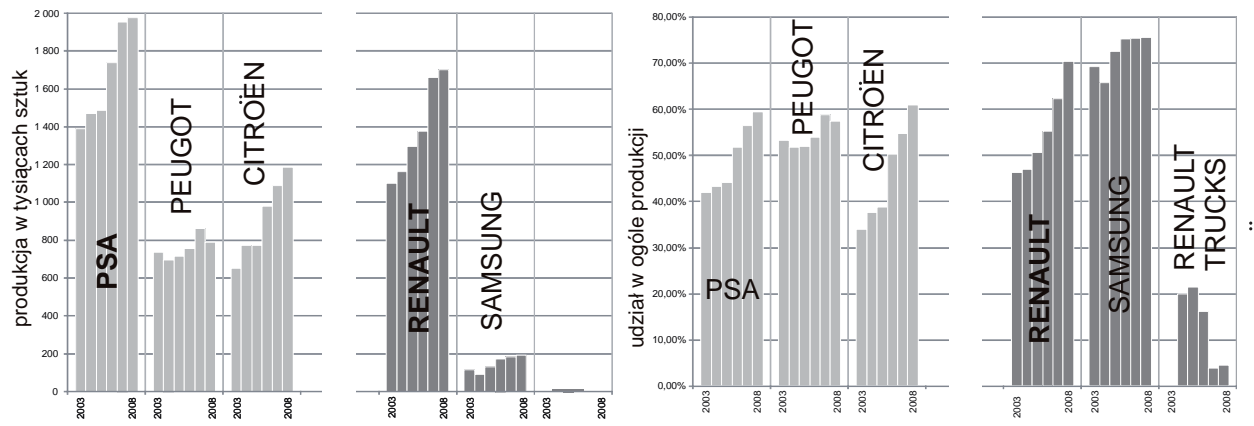

w analizie pominięto zachodnie marki przejęte przez koncerny np. Dacia

Ryc. 9. Produkcja francuskich koncernów samochodowych poza Francją w latach 2003-2008

Źródło: opracowanie własne na podstawie danych Comité des Constructeurs Français d'Automobiles

Koncern Renault posiada 17 zakładów produkcyjnych poza Francją, a PSA 23 (ryc. 11). W rozmieszczeniu zakładów według typu nie da się zaobserwować większej prawidłowości. Inwestycje obu koncernów skupiają się w Europie, na Bliskim Wschodzie oraz w Ameryce Południowej. W 2007 r. powstały duże fabryki w Iranie, planowane są inwestycje w Rosji i Holandii. Porównując tempo zmian wielkości produkcji w latach 2003-2008, można zauważyć wzrost produkcji samochodów francuskich poza kontynentem europejskim, głównie w Argentynie, Brazylii i Chinach, podczas gdy w Hiszpanii nastąpił ponaddziesięciokrotny spadek (ryc. 13). Potwierdza się zatem tendencja do przenoszenia produkcji przemysłu samochodowego do krajów rozwijających się. Wpływają na to nie tylko koszty produkcji, ale również koszty transportu na nowe rynki zbytu. 


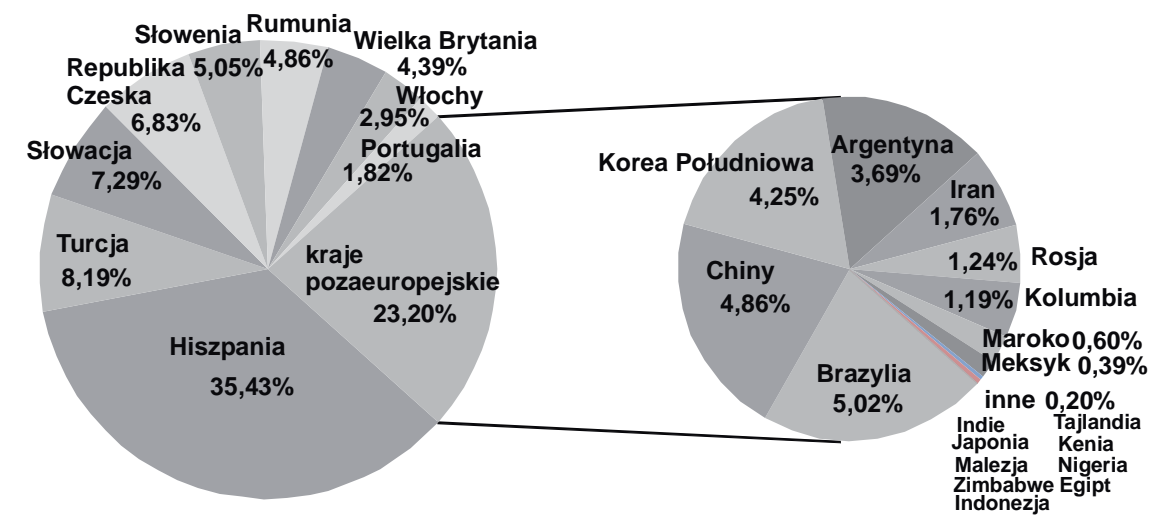

Ryc. 10. Produkcja francuskich koncernów samochodowych poza Francją w latach 2003-2008

Źródło: opracowanie własne na podstawie danych Comité des Constructeurs Français d’Automobiles

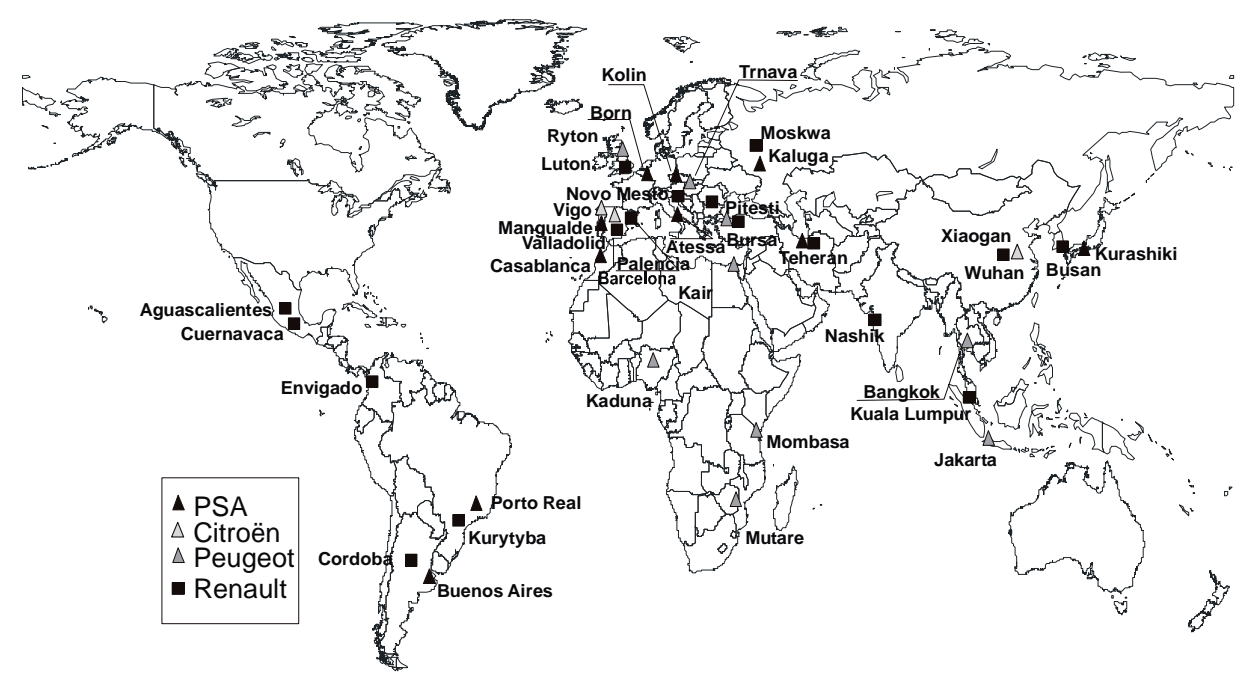

Ryc. 11. Zakłady francuskich korporacji samochodowych na świecie latach 2003-2008

Źródło: opracowanie własne na podstawie danych Comité des Constructeurs Français d'Automobiles

O procesie delokalizacji produkcji świadczy również spadek wielkości produkcji samochodów w fabrykach francuskich. We wszystkich dziesięciu zakładach samochodowych nastąpił spadek lub stagnacja produkcji. Jednakże w dalszym ciągu większość zagranicznych fabryk produkuje mniej niż zakłady francuskie. Wyjątkiem są tu zakłady w Vigo i Palencia w Hiszpanii oraz Kolin w Republice Czeskiej i Tarnava na Słowacji (ryc. 14). Jednakże większość zakładów zlokalizowanych poza Francją wykazuje większą dynamikę wzrostu produkcji od zakładów francuskich. Należy tu zaznaczyć, że na proces delokacji zakładów w dużej mierze wpływają uwarunkowania polityczne, zwłaszcza w przypadku koncernu Renault, w którym głównym udziałowcem jest państwo. 


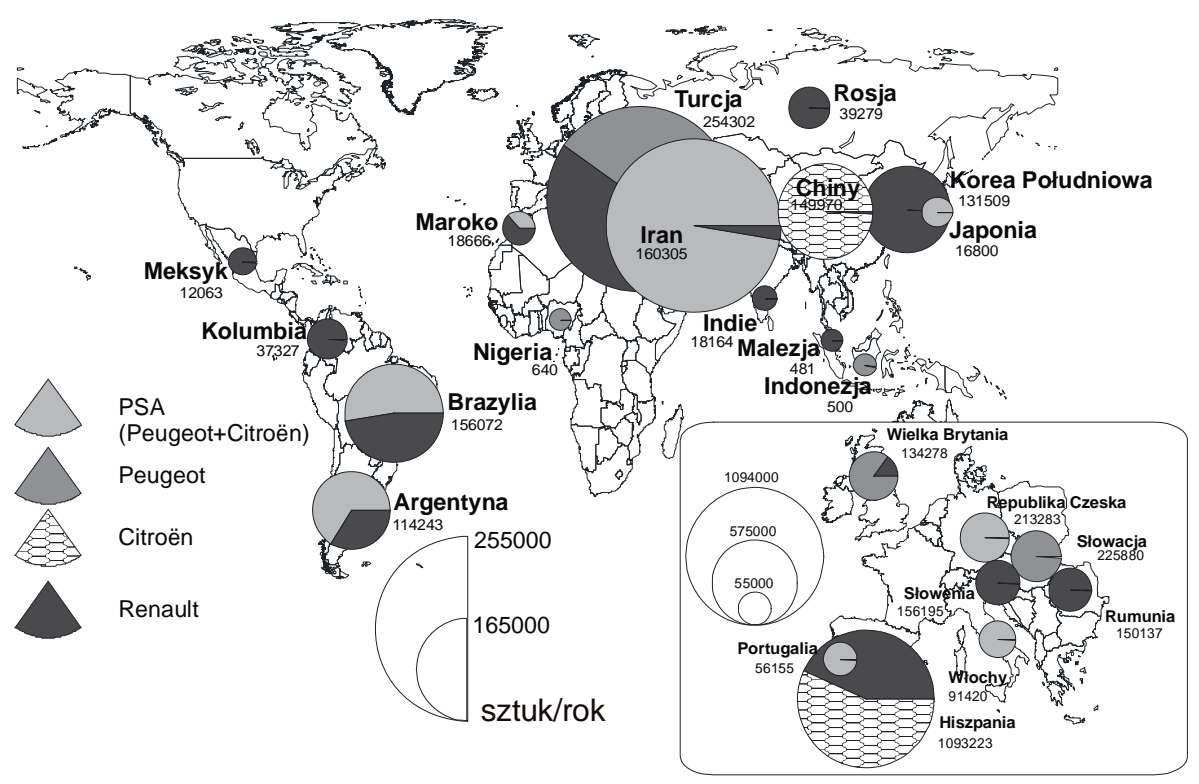

Ryc. 12. Wielkość produkcji francuskich koncernów samochodowych w $2008 \mathrm{r}$.

Źródło: opracowanie własne na podstawie danych Comité des Constructeurs Français d'Automobiles

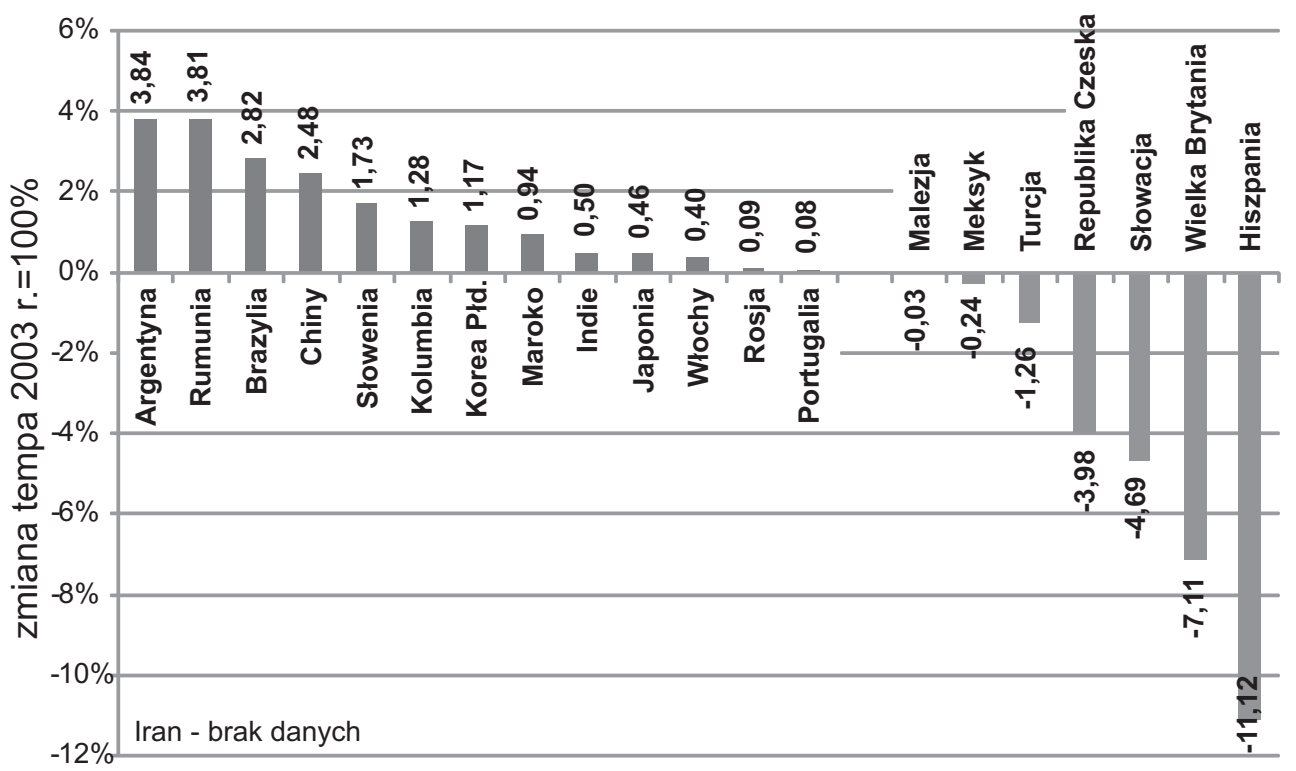

Ryc. 13. Zmiana udziału produkcji francuskich koncernów samochodowych poza Francją w latach 2003-2008

Źródło: opracowanie własne na podstawie danych Comité des Constructeurs Français d'Automobiles 


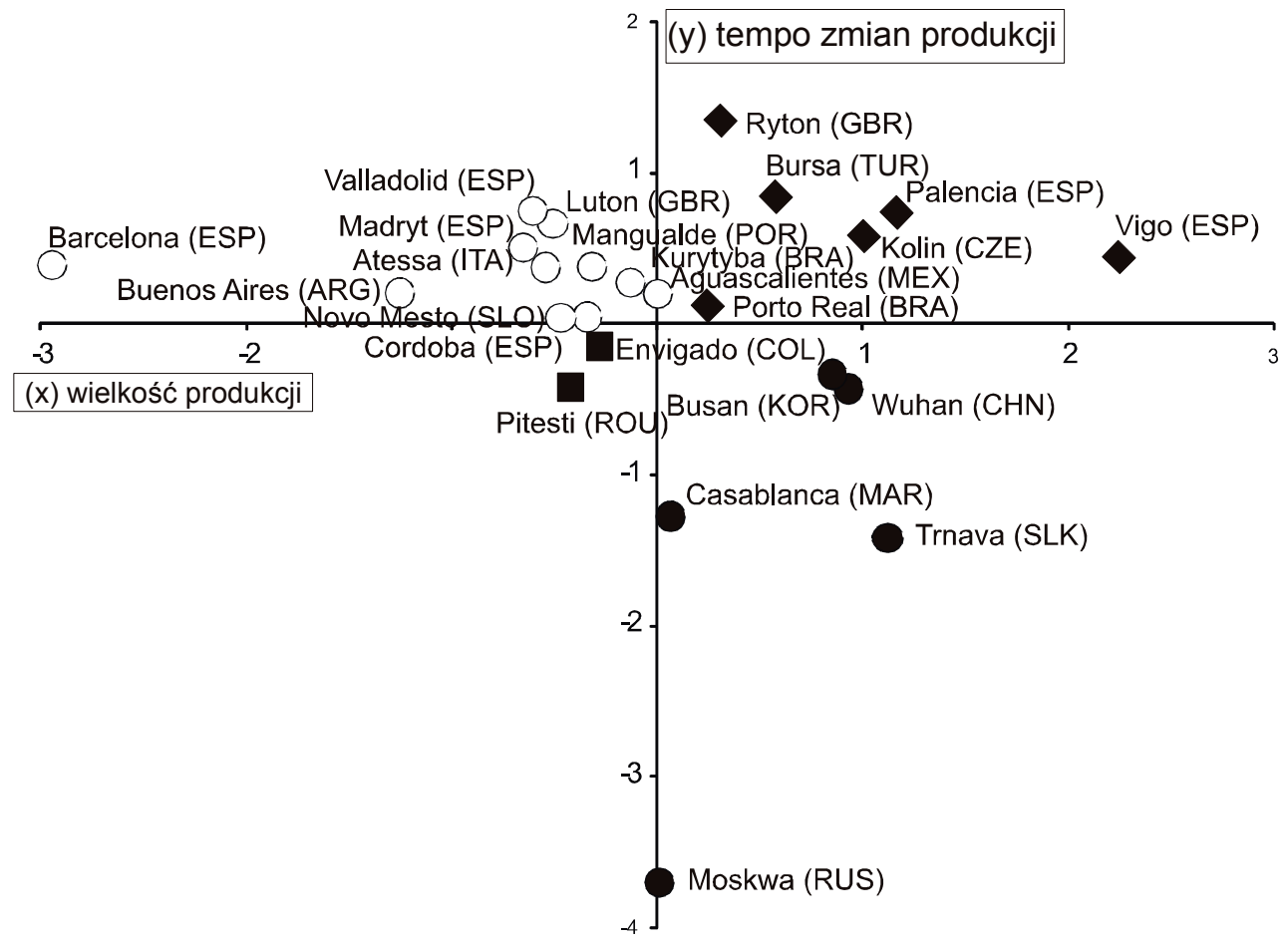

Ryc. 14. Zmiana udziału produkcji francuskich koncernów samochodowych poza Francją w latach 2003-2008

Źródło: opracowanie własne

\section{WNIOSKI}

Podsumowując, należy stwierdzić, że pomimo fluktuacji gospodarczych produkcja przemysłu samochodowego na świecie od lat osiemdziesiątych XX w. utrzymuje stałą tendencję wzrostową. Od początku XXI w. prymat w światowej produkcji przemysłu samochodowego przejmuje region azjatycki, przy wyraźnym spadku wielkości produkcji w Europie i Ameryce Północnej. Największy wzrost produkcji samochodów w latach 1980-2008 wystąpił w państwach rozwijających się Azji, Europy Środkowo-Wschodniej i Ameryki Południowej. Jednym z rozwiniętych państw Europy Zachodniej, w którym odnotowano największy spadek produkcji samochodów, jest Francja. Wynika to z delokalizacji zakładów produkcyjnych z terytorium Francji - produkcja za granicą wzrosła w ciagu ostatnich 10 lat z 40\% do 64\%. O znaczeniu przemysłu samochodowego dla Francji mogą świadczyć próby zahamowania procesu delokalizacji przemysłu motoryzacyjnego przez prezydenta Francji Nicolasa Sarkozy'ego. Wynika to nie tylko z faktu, że jeden na dziesięciu zatrudnionych we Francji związany jest bezpośrednio lub pośrednio z przemysłem samochodowym, ale również z przyczyn strategicznych. PSA i Renault zajmują pierwsze i drugie miejsce w liczbie 
zgłoszonych patentów we Francji. Jednakże, jak zauważa większość analityków, procesów delokalizacji we współczesnym zintegrowanym globalnym świecie nie da się powstrzymać.

\section{Literatura}

Deardorff A., 2004, A Trade Theorist's Take on Skilled-Labor Outsourcing, Research Seminar in International Economics, Gerald R. Ford School of Public Policy, The University of Michigan, Discussion Paper, nr 519.

Deardorff A., 2005, Gains from Trade and Fragmentation, Research Seminar in International Economics, Gerald R. Ford School of Public Policy, The University of Michigan, Discussion Paper, nr 543.

Domański B., Guzik R., Gwosdz K., 2005, The new spatial organization of automotive industry in Poland in the context of its changing role in Europe, Studia Regionalia, 15, s. 153-171.

Gierańczyk W., 2008, Problematyka definiowania zmian $w$ tendencjach lokalizacyjnych przedsiębiorstw przemystowych $w$ dobie globalizacji, [w:] Problematyka badawcza geografii przemy$s t u$, red. Z. Zioło, T. Rachwał, Prace Komisji Geografii Przemysłu PTG nr 11, Wydawnictwo Naukowe Akademii Pedagogicznej, Warszawa-Kraków, s. 86-97

Hanson G., Mataloni J., Slaughter J., 2004, Vertical production networks in multinational firms, NBER Working Paper, No. 9723.

Kilar W., Cieluch M., 2008, Kształtowanie się i organizacja przestrzenna korporacji ponadnarodowej Honda, [w:] Procesy transformacji ukladów przestrzennych przemystu na tle zmieniajacego się otoczenia, red. Z. Zioło, T. Rachwał, Prace Komisji Geografii Przemysłu PTG nr 10, Wydawnictwo Naukowe Akademii Pedagogicznej, Warszawa-Kraków, s. 188-203.

Merkisz-Guranowska A., J. Merkisz, 2007, Wybrane aspekty globalizacji w przemyśle motoryzacyjnym, Zeszyty Naukowe Politechniki Poznańskiej, Budowa Maszyn i Zarządzanie Produkcją, nr 6, s. 99-110.

Moszyński. M, 2007, Procesy delokalizacji we wspótczesnej gospodarce światowej - szansa czy zagrożenie dla polskiego rynku pracy?, [w:] Wykorzystanie zasobów pracy we wspótczesnej gospodarce, red. D. Kopycińska, Katedra Mikroekonomii Uniwersytetu Szczecińskiego, Szczecin, s. $39-48$.

Oberhauser A. ,1987, Labour, Production and the State: Decentralization of the French Automobile Industry, Regional Studies, Vol. 21, No. 5, s. 445-458

Pavlínek, P., Domański, B., Guzik, R., 2009, Industrial Upgrading Through Foreign Direct Investment in Central European Automotive Manufacturing, European Urban and Regional Studies, Vol. 16, No. 1, 43-63.

Radło M. J., 2006, Globalizacja, inwestycje bezpośrednie, delokalizacja, offshoring, outsourcing: podstawowe definicje, [w:] Delokalizacja w rozszerzonej Unii Europejskiej - perspektywa wybranych państw członkowskich UE. Wnioski dla Polski, red. E. Nowicka, Urząd Komitetu Integracji Europejskiej, Departament Analiz i Strategii, Warszawa.

Samuelson P. A., 2004, Where Ricardo and Mill Rebut and Confirm Arguments of Mainstream Economists Supporting Globalization, Journal of Economic Perspectives, Vol. 18, No 3.

Wiedermann K., 2007, Regionalne efekty mnożnikowe rozwoju przemystu motoryzacyjnego w aktywizacji gospodarczej województwa ślaskiego, [w:] Rola przedsiębiorczości w aktywizacji gospodarczej, red. Z. Zioło, T. Rachwał, Przedsiębiorczość - Edukacja, nr 3, Kraków, s. 24-35.

Wiedermann K., Koncepcja efektów mnożnikowych $w$ wyznaczaniu wplywu przedsiębiorstw na otoczenie społeczno-gospodarcze, [w:] Problematyka badawcza geografii przemystu, red. Z. Zioło i T. Rachwał, Prace Komisji Geografii Przemysłu PTG nr 11, Wydawnictwo Naukowe Akademii Pedagogicznej, Warszawa-Kraków, s. 98-106. 
Wójtowicz M., 2008, Rozwój przemystu samochodowego w Brazylii w latach 1957-2005, [w:] Procesy transformacji układów przestrzennych przemystu na tle zmieniajacego się otoczenia, red. Z. Zioło, T. Rachwał, Prace Komisji Geografii Przemysłu PTG nr 10, Wydawnictwo Naukowe Akademii Pedagogicznej, Warszawa-Kraków, s. 140-153.

Wójtowicz M., 2009, Wpływ globalizacji i integracji w ramach MERCOSUR na wymianę handlowa produktów przemystu samochodowego Brazylii w latach 1990-2006, [w:] Wpływ procesów globalizacji i integracji europejskiej na transformacje struktur przemystowych, red. Z. Zioło, T. Rachwał, Prace Komisji Geografii Przemysłu PTG nr 12, Wydawnictwo Naukowe Akademii Pedagogicznej, Warszawa-Kraków, s. 63-78.

\section{Contemporary processes of internationalization of production and delocalisation of the French automotive industry}

The following article deals with the contemporary processes of internationalization of production and delocalisation of automotive industry, with a particular reference to France. On the basis of statistical data referring to the rate of production and its structure, the article presents the changes in the concentration of worldwide car production with a particular reference to French car concerns. Asia is the most developing market for auto manufacturing in the 21 st century, whereas a decrease in auto production can be observed in Europe and North America. In France in the last 10 years there has been an increase in the car production abroad from $40 \%$ to $64 \%$.

dr Sławomir Dorocki

Uniwersytet Pedagogiczny im. Komisji Edukacji Narodowej w Krakowie

Instytut Geografii

Zakład Przedsiębiorczości i Gospodarki Przestrzennej

sdorocki@up.krakow.pl 